\title{
Comparison of the effect of W-shaped and linear skin incisions on scar visibility in bilateral external dacryocystorhinostomy
}

This article was published in the following Dove Press journal:

Clinical Ophthalmology

27 November 2015

Number of times this article has been viewed

\section{Bulent Yazici}

Department of Ophthalmology, Uludag University, Bursa, Turkey
Correspondence: Bulent Yazici Department of Ophthalmology, Uludag University, Bursa 16059, Turkey

Email byazici@uludag.edu.tr

\section{Dear editor}

The article entitled "Comparison of the effect of W-shaped and linear skin incisions on scar visibility in bilateral external dacryocystorhinostomy" by Ekinci et al ${ }^{1}$ was published in Clinical Ophthalmology; I reviewed this paper for another journal (Journal of Ophthalmology) several months ago before it appeared in your journal.

It seems that the authors submitted their rejected paper to your journal, after making some unethical, methodological changes.

The major differences between the two versions of the same manuscript are as follows:

The rejected manuscript states that the study was conducted "between January 2009 and June 2012" (42 months). However, the published manuscript states that the study was conducted "between June 2011 and June 2012" (12 months).

The rejected manuscript states that "The mean follow-up time was 14.1 $\pm 5.84(7-25)$ months for the WS incision group and 29.4 \pm 5.08 (24-40) months for the LS incision group". These periods and follow up times show that the dacryocystorhinostomy (DCR) surgeries with linear shape (LS) incision were performed about 15 months before the DCR surgeries with W-shaped (WS) incisions. These follow up times, however, are removed from the published version of the manuscript.

Another significant issue arises when the scar assessments times are compared in the rejected and published versions. In the rejected version, the scar assessment time was reported as "6 months after the second surgery", "Scars were scored 6 months after the second surgery [...]" (in the Abstract) and "The skin incisions were assessed 6 months after the second procedure by [...]" (in the Materials and methods). Taking into account the mean follow-up times reported in the rejected manuscript, the scar assessment must take place about 15 months apart for each group.

However, the published paper reports that the scar assessment took place " 6 months after each procedure". See the Materials and methods section paragraph 1 and 3 stating: "The skin incisions were assessed 6 months after each procedure by [...]" and "The surgeries were not simultaneous, so assessment of scar visibility on each side was done at the 6-month postoperative visit to prevent one side being more healed than the other at evaluation."

This last sentence is like a response to one of the reviewer's comments on the rejected manuscript and explains the motivation of the authors for this change in the published version. Given that both the rejected manuscript and the published paper 
derived results from the same cohort of patients, a serious question arises with regard to the truthfulness of the method and data in the published paper.

Another potential issue involves a schematic drawing of the WS incision included in the rejected version of the manuscript. This drawing shows that the arms of the WS incision are unequal: the two inner arms toward the nasal dorsum are $8 \mathrm{~mm}$ in length (two times longer than the outer arms). However, in the methods section of the text (in the both rejected and published versions), the $\mathrm{W}$ shape was described as follows: "The W shape was formed by three consecutive equilateral triangles having sides $4 \mathrm{~mm}$ in length with two tips and one base that showed the medial canthus". Another paper written by these authors, which was previously published in the journal Orbit, also included the similar discrepancy between the drawing and text. ${ }^{2}$ This discrepancy becomes unnoticeable when the authors removed the drawing from the published version.

In addition to these discrepancies, another issue I have with this paper is that the idea of a W-shaped incision is presented as original. This idea appeared first in our department in the form of a specialization thesis, in which equal W-shaped and linear incisions were compared. ${ }^{3}$ This technique represents a significant advancement in external dacryocystorhinostomy surgery. I have discussed this technique and performed live surgeries at several national meetings in Turkey over the past 8 years. Although Ekinci et al knew about these presentations and the thesis, they presented this method as original research. It is disappointing when fellow academicians adopt such strategies for academic promotion.

\section{Disclosure}

The author reports no conflict of interest in this communication.

\section{References}

1. Ekinci M, Cağatay HH, Gokce G, et al. Comparison of the effect of W-shaped and linear skin incisions on scar visibility in bilateral external dacryocystorhinostomy. Clin Ophthalmol. 2014;8:415-419.

2. Ekinci M, Cağatay HH, Oba ME, et al. The long-term follow-up results of external dacryocystorhinostomy skin incision scar with "W incision". Orbit. 2013;32(6):349-355.

3. Ayvaz AT. Eksternal dakriyosistorinostomi ameliyatında $W$ şeklinde cilt kesisi. [W-shaped skin incision for external dacryocystorhinostomy] [specialization Master's thesis] Uludag University Publication, Bursa; 2010. Turkish. 


\section{Authors' reply}

Metin Ekinci'

Halil Hüseyin Çağatay'

Gokcen Gokce ${ }^{2}$

Erdinç Ceylan ${ }^{3}$

Sadullah Keleș ${ }^{4}$

Özgür Çakici ${ }^{5}$

Mehmet Ersin Oba'

Zeliha Yazar'

'Department of Ophthalmology, University of Kafkas, ${ }^{2}$ Department of Ophthalmology, Sarikamis Military Hospital, Sarikamis, Kars, ${ }^{3}$ Ophthalmology Clinic, Erzurum Training and Research Hospital, ${ }^{4}$ Department of Ophthalmology, University of Atatürk, Erzurum, ${ }^{5}$ Department of Ophthalmology, University of Mugla Sitki Kocman, Muğla, Turkey

Correspondence: Metin Ekinci

Department of Ophthalmology, University of Kafkas, Kars, 36100,

Turkey

Email drmetinekinci@gmail.com

\section{Dear editor}

We thank Dr Yazıc1 for his kind comments and the opportunity he has provided for clarifying our work. We also thank Dr Yazıcı for sharing his study which he cited as "Ayvaz AT. Eksternal dakriyosistorinostomi ameliyatında $\mathrm{W}$ şeklinde cilt kesisi. [W shaped skin incision for external dacryocystorhinostomy] specialization thesis in ophthalmology, Uludag University Publication, Bursa, 2010". As this study is not indexed in the international and most of the national medical databases, we were unfortunately unable to find and cite it. We apologize for the oversight of not including this study as a reference.

In this study, no unethical changes were made between the two versions. Our article was revised in accordance with the reviews received upon submission to the first journal.

As we stated in the version of our article published in Orbit, ${ }^{1}$ our study was designed in 2009. We observed our patients, operated with classical vertical incision in 2009 and 2010, which is the incision type typically applied in the literature. Our study is based on a patient group whose scar ratings were recorded in the postoperative month 6 and another patient group who we started to operate by W-incision type after obtaining the approval of the local ethics committee. The only reason in obtaining the approval of the local ethics committee after the planning of the study is that the local ethics committee was established and started to function as of 2011. Therefore, it was written in the first version of our article that the study was conducted between January 2009 and June 2012. The approval of the ethics committee dates back to 2011 as mentioned in the article.
The criticism we receive from reviewers regarding our article are very important to us as we believe that they will enhance the scientific merit of our article by pointing out the deficiencies and mistakes. It was a valuable criticism that postoperative scar visibility may change over time. In this regard, we used the scar scores in month 6 for our patients who underwent linear or $\mathrm{W}$ incision and refrained from mentioning the total follow-up times in the final version of our article in order to avoid any possible confusion in this regard. In conclusion, the surgical operations were not conducted on the groups simultaneously and scar evaluations were made in both groups in the postoperative month 6 .

In his letter, Dr Yazıcı claimed that "there are differences between the two studies in terms of the definition of our incision". It must be emphasized that it is rather difficult to define surgical methods merely in writing. Historically, schematic description or use of figures are generally accepted in the medical literature. It is normal that Dr Yazıcı considered differences or incomprehensibility in his criticism in this regard, which might well be due to our insufficient description, therefore we suggest that our readers take the figure into consideration when reading the description of the incision type and evaluate both the description and the figure in combination.

Dr Yazıc1 states: "In addition to these discrepancies, another issue I have with this paper is that the idea of a W-shaped incision is presented as original". In the discussion section of our article we state, contrary to Dr Yazici's accusations, that the W-shaped skin incision was not presented as original or as our own technique. In exact words, we stated: "In cosmetic surgery, Z-plasty, S-plasty and W-plasty are well-known skin reparation techniques used in scar revisions to relax the tension on the wound edges where the skin is resistant such as periorbital, perioral and nasolabial regions." Further, in the same paragraph we state: "We believe that the W-shaped incision is a modified form of Z-plasty". This section of our study reflects our approach to Dr Yazıcı's claims.

Another point to be emphasized is that since Dr Yazic1 described our incision as "unequal W shaped", one would expect that his incision shape should be different from the one described in our study. Thus, if he claims to know an incision shape that results in better scar healing, he should provide us an opportunity to discuss and benefit from this technique by publishing it in the literature.

In his letter, Dr Yazıc1 states: "This idea first appeared in our department in the form of a specialization thesis in which equal W-shaped and linear incisions were compared. This technique represents a significant advancement in external dacryocystorhinostomy (DCR) surgery." I wish to 
point out that $\mathrm{W}$ incision is not a new invention for me and my colleagues; it has already been used for a long time in cosmetic surgery to prevent the development of scar tissue. On the face, w/z-plasties are particularly useful around the eye, around the mouth, and in nasolabial creases. ${ }^{2-6}$ When writing our article, we were careful not to make any assertions that this technique belongs to us as we were aware that this incision is not a new technique. Therefore, in our study, we only published the results of the incisions we practiced on our patients. If in the future, a researcher practices the same incision on his patients and publishes his results that either $\mathrm{W}$ incision reduces scar tissue development or that it increases scar tissue development, we do not think we have the right to blame this researcher for stealing our idea.

Both at the time of planning our study and today, we have been unable to find Dr Yazıc1's study which he cited as "Ayvaz AT. Eksternal dakriyosistorinostomi ameliyatında $\mathrm{W}$ şeklinde cilt kesisi. [W shaped skin incision for external dacryocystorhinostomy] specialization thesis in ophthalmology, Uludag University Publication, Bursa, 2010" in any of current standard scientific research websites such as PubMed, Google Scholar, Science Direct, Scopus, Ovid, Türk Oftalmoloji Gazetesi (Turkish Ophthalmology Journal), Türkiye Klinikleri Tıp Bilimleri Dergisi (Turkish Journal of Medical Clinics), Türk Tıp Veri Tabanı (Turkish Medical Database), ULAKBİM Ulusal Veri Tabanları (ULAKBIM National Database), or uvt.ulakbim.gov.tr/tip, MN Oftalmoloji ve Üniversitelerin Tıp fakülteleri Dergileri (Medical Journals of Medicine Faculties). In Turkey, in order to achieve the certificate in ophthalmology one must present a "specialization thesis" according to the Turkish legislation. In his letter, Dr Yazıcı mentions such a thesis. It is obligatory for this thesis to be printed (in Turkish) but in order for this thesis to be cited as a reference in clinical research studies it must also be published in clinical national/international research journals and thus made known. Such publication was not made therefore the study is not known to us. This is the reason why it has never been cited neither by us nor by any research team as a reference until now.

Another point worth emphasizing is that ophthalmologic meetings and the literature help doctors share their experiences, and reach successful results by not repeating the mistakes other doctors had made in the past. Therefore, it is very likely that young ophthalmologists to try to find their own solutions to the problems using the knowledge and experiences of other colleagues presented during such meetings. Thus, we believe that even if the W-shape incision idea had been presented by Dr Yazıcı before, it would have been a very natural process and not plagiarism for ophthalmologists to get inspired and benefit from the work of such an experienced ophthalmologist as Dr Yazıcı. We have no notion of refraining from referencing our sources, on the contrary we find such a practice completely unethical. It will be observed in the article in question that we referenced 2 studies of Dr Yazıc1, which we found and made use of in the literature. However, we do not find it ethical to be accused of not citing a study which has not yet entered into most of the indexes. Obviously, it is impossible to scan all libraries and congress presentations in the world for each study. Articles and studies in similar subjects are published throughout the world simultaneously or at different times, and it is deeply upsetting for us that the matter has come to this point.

It is also worth mentioning that our study was presented at various scientific meetings in part: as a poster, at the 3rd Congress on Controversies in Ophthalmology. ${ }^{7}$ It was also presented as an oral presentation at the 46th Turkish Ophthalmological National Congress, 17-21 October 2012 in Antalya, Kemer, Turkey. We would like to emphasize that while presenting these studies in various congresses, we did not receive any comments, critics or feedback from Dr Yazıcı.

In conclusion, we thank Dr Yazıcı for his interest in our article. Scar tissue development was one of the most important problems in external DCR surgeries for us. Our aim in writing this study was to contribute to the literature by adopting the surgery principles in the literature to DCR incision. We believe that our study was performed, written and published in accordance with ethical principles.

\section{Disclosure}

The authors report no conflicts of interest in this communication.

\section{References}

1. Ekinci M, Çağatay HH, Oba ME, et al. The long-term follow-up results of external dacryocystorhinostomy skin incision scar with "W incision" Orbit. 2013;32(6):349-355.

2. Reish RG, Eriksson E. Scar treatments: preclinical and clinical studies. J Am Coll Surg. 2008;206(4):719-730.

3. Shockley WW. Review Scar revision techniques: z-plasty, w-plasty, and geometric broken line closure. Facial Plast Surg Clin North Am. 2011; 19(3):455-463.

4. Rohrich RJ, Zbar RI. A simplified algorithm for the use of Z-plasty. Plast Reconstr Surg. 1999;103(5):1513-1517; quiz 1518.

5. Roggendorf E. The planimetric Z-plasty. Plast Reconstr Surg. 1983; 71(6):834-842

6. Burm JS, Oh SJ. Direct local approach through a W-shaped incision in moderate or severe blowout fractures of the medial orbital wall. Plast Reconstr Surg. 2001;107(4):920-928.

7. Ekinci M, Aslan B, Çağatay HH, Yazar Z, Oba E. Poster presented at 3rd Congress on Controversies in Ophthalmology. March 22-25, 2012. Istanbul, Turkey. Management of External Dacryocystorhinostomy Skin Incision Scar With “ $W$ ” incision. 
Dove Medical Press encourages responsible, free and frank academic debate. The content of the Clinical Ophthalmology 'letters to the editor' section does not necessarily represent the views of Dove Medical Press, its officers, agents, employees, related entities or the Clinical Ophthalmology editors. While all reasonable steps have been taken to confirm the content of each letter, Dove Medical Press accepts no liability in respect of the content of any letter, nor is it responsible for the content and accuracy of any letter to the editor.

Clinical Ophthalmology

\section{Publish your work in this journal}

Clinical Ophthalmology is an international, peer-reviewed journal covering all subspecialties within ophthalmology. Key topics include: Optometry; Visual science; Pharmacology and drug therapy in eye diseases; Basic Sciences; Primary and Secondary eye care; Patien Safety and Quality of Care Improvements. This journal is indexed on

PubMed Central and CAS, and is the official journal of The Society of Clinical Ophthalmology (SCO). The manuscript management system is completely online and includes a very quick and fair peer-review system, which is all easy to use. Visit http://www.dovepress.com/ testimonials.php to read real quotes from published authors. 